\title{
Odnos jugoslavenskoga i albanskoga komunističkog vrha od kraja Drugoga svjetskog rata do prekida odnosa (1945. - 1948.)
}

\author{
BORIS SULJAGIĆ \\ Hrvatski državni arhiv \\ Zagreb, Hrvatska \\ bsuljagi@arhiv.hr
}

\begin{abstract}
Članak se bavi temom odnosa vrha jugoslavenske i albanske komunističke partije od kraja Drugoga svjetskog rata do prekida odnosa sredinom 1948. godine. Do proljeća 1947. odnosi dviju partija poticali su razvoj gospodarske i vojne suradnje dviju zemalja. Ipak, patronat vrha Komunističke partije Jugoslavije nad Komunističkom partijom Albanije i samom Albanijom bio je prevelik za dio albanskoga rukovodstva. Kada je jugoslavenski vrh u proljeće 1947. odbio albanski gospodarski plan, odnosi su se počeli znatnije pogoršavati, što se sve više prenosilo i na odnose između Albanaca i Jugoslavena na radu u toj zemlji. Sovjetski Savez intervenirao je kada je Federativna Narodna Republika Jugoslavija htjela poslati divizije u Albaniju za zaštitu njezinih južnih granica s Grčkom. Do tada su (početkom 1948.) gospodarski odnosi dviju zemalja već pretrpjeli znatnu štetu. No, najveća šteta nastala je u odnosima među dvjema partijama i među ljudima. Međunarodni sukob Federativne Narodne Republike Jugoslavije i Sovjetskoga Saveza potaknut Rezolucijom Informbiroa bio je tako samo katalizator prekida već ozbiljno narušenih odnosa.
\end{abstract}

Ključne riječi: albanski komunisti; jugoslavenski komunisti; gospodarska suradnja; vojna suradnja; gospodarski plan; patronat

\section{Uvod}

O temi odnosa jugoslavenskoga i albanskoga komunističkog vrha od kraja Drugoga svjetskog rata do prekida odnosa dviju država i partija (1945. - 1948.) pisao je Vladimir Dedijer, član vodstva Komunističke partije Jugoslavije (KPJ) i istaknuti publicist, u svojoj monografiji Jugoslovensko-albanski odnosi (19391948), objavljenoj u Beogradu 1949. godine. Prikazao je ulogu KPJ u stvaranju Komunističke partije Albanije (KPA) 1941., ratno razdoblje u Albaniji i tri 
poslijeratne godine. Nakon prekida odnosa o odnosima Jugoslavije i Albanije pisalo se malo ili gotovo ništa.

Kontakti Albanije i Kosova, tada pokrajine u sastavu jugoslavenske republike Srbije, sedamdesetih godina XX. stoljeća i nemiri na Kosovu 1981. pojačali su zanimanje za Albance kao narod i za Albaniju kao zemlju. U zborniku radova Albanci, objavljenom 1984. u Ljubljani, Janez Stanič u svojem se članku dotaknuo odnosa dviju država 1945. - 1948., navodeći da je Josip Broz Tito bio za nacionalnu ravnopravnost, što je značilo da Albanci na Kosovu moraju biti ravnopravni sa Srbima i da se unutarnji razvoj Albanije uvijek tijesno vezivao s njezinim vanjskim savezništvima. ${ }^{1}$ Panajot Pljaku u knjizi Nasilje nad albanskom revolucijom dao je svoje opise albanskih komunističkih vođa, pa je po njemu Enver Hoxha bio prevrtljivac i željan apsolutne vlasti. ${ }^{2} \mathrm{U}$ člancima o Albaniji objavljivanim u časopisima i novinama na području Jugoslavije tijekom osamdesetih godina XX. stoljeća autori su se najviše bavili albanskom politikom prema Jugoslaviji nakon 1948. godine. Neki od njih dali su osvrte i na razdoblje prvih triju poslijeratnih godina. Duško Topalović istaknuo je da su Albanija i Jugoslavija od 1945. do 1948. imale zajednički interes u čuvanju Otrantskih vrata, odnosno izlaza iz Jadranskoga mora, jer su zapadne zemlje vodile politiku okruživanja socijalističkih zemalja. ${ }^{3}$ Gordan Ranitović uočio je da je albanska politika izbjegavanja uzimanja kredita od drugih zemalja bila nedosljedna budući da su 1948. ostali dužni Jugoslaviji, poslije su ostali dužni Sovjetskom Savezu nakon prekida odnosa s njim, a konačno su ostali dužni socijalističkoj Kini nakon prekida odnosa. ${ }^{4}$ Vojin-Vojo Todorović napisao je da je ukupna jugoslavenska pomoć Albaniji od ljeta 1945. do sredine 1948. iznosila oko 705 milijuna dinara. Da bi objasnio o kolikom je iznosu riječ, rekao je da je tada puška stajala 1.700 dinara, a putnički automobil oko 20.000 dinara. $^{5}$

Peter Danylow u svojoj je monografiji o vanjskopolitičkim odnosima Albanije s Federativnom Narodnom Republikom Jugoslavijom (FNRJ) i Sovjetskim Savezom iz 1982. naglasak stavio na gospodarsku suradnju. Zanimljivo je njegovo tumačenje o prijeporima između FNRJ i Albanije oko tečaja nove albanske valute. Ipak, nije koristio arhivsko gradivo. ${ }^{6}$

U Beogradu je 2001. objavljena prevedena sinteza Petera Bartla o Albancima od srednjega vijeka do danas. Bartl govori o savezu Albanije i Jugoslavije i ovisnosti Albanije o Jugoslaviji između 1945. i 1948. te da Albanija praktički nije mogla voditi vlastitu vanjsku politiku. ${ }^{7}$ Do prekretnice u odnosima došlo je kada je izbio sukob između Sovjetskoga Saveza i FNRJ u

1 STANIČ, „Albanija Enverja Hoxhe”, 147-148.

2 PLJAKU, Nasilje nad albanskom revolucijom, 35.

3 TOPALOVIĆ, „Geopolitičke komponente albanskih savezništava”, 154-156.

${ }^{4}$ Gordan RANITOVIĆ, „Albanija - principi i potrebe”, NIN (Beograd), 21. 12. 1986., 50-51.

5 Vojin-Vojo TODOROVIĆ, „A onda - četrdeset osma”, Borba (Beograd), 12. 1. 1989., 13.

6 DANYLOW, Die aussenpolitischen Beziehungen Albaniens zu Jugoslawien und zur UdSSR, 71.

BARTL, Albanci, 233-235. 
proljeće 1948. godine. Centralni komitet KPA 29. lipnja te godine podržao je Rezoluciju Informbiroa i osudio vođe KPJ kao izdajice i trockiste. ${ }^{8}$

Glavna literatura koja se bavi odnosima dvaju partijskih vrhova 1945. 1948. sastoji se od dvije knjige objavljene 2011. godine. Tada je Jurij Hadalin u Ljubljani objavio Boj za Albanijo: propad jugoslovanske širitve na Balkan, a Aleksandar Životić knjigu Jugoslavija, Albanija i velike sile (1945-1961). Hadalin je u Nečakovu zborniku iz 2018. objavio i članak o Savi Zlatiću, predstavniku Centralnoga komiteta KPJ pri Centralnom komitetu KPA od 1946. do 1948. godine.

Osobni arhivski fond Save Zlatića pohranjen je u Hrvatskom državnom arhivu i služi kao važan izvor za razumijevanje odnosa dvaju partijskih vrhova i dopunjava se s navedenom literaturom.

Kada se vjerovalo u vječno savezništvo dviju zemalja

Pred kraj Drugoga svjetskog rata, 28. travnja 1945., Vlada Demokratske Federativne Jugoslavije (DFJ) kao prva u svijetu priznala je albansku vladu general-pukovnika Envera Hoxhe i u svibnju otvorila veleposlanstvo u Tirani. ${ }^{9}$ Time su odnosi KPJ i KPA, koje su 1945. preuzele vlast u svojim zemljama, podignuti na državnu razinu. Enver Hoxha bio je na čelu Albanije kao predsjednik Vlade i kao vodeća osoba u KPA. Do 1948. vodio je i projugoslavensku i prosovjetsku politiku, u skladu s potrebama održanja na vlasti. Dotadašnji šef vojne misije Jugoslavenske armije Velimir Stojnić postavljen je za veleposlanika DFJ u Albaniji. ${ }^{10}$ Stojnić je u ratu postao politički komesar korpusa Narodnooslobodilačke vojske Jugoslavije (NOVJ). Odnosi KPJ i KPA od 1941. do kraja Drugoga svjetskog rata razvijali su se tako da je KPJ snažno utjecala na razvoj KPA, a jugoslavenski komunistički vrh smatrao je da se starateljstvo KPJ nad KPA mora reflektirati i na međudržavne odnose. Članovi KPJ sudjelovali su na sastancima Politbiroa KPA. Ubrzo nakon jugoslavenskoga priznanja Albanije Milovan Đilas, član Centralnoga komiteta KPJ i Politbiroa te ratni član Vrhovnoga štaba NOVJ-a, posjetio je Albaniju i u lipnju 1945. o svojim opažanjima govorio na sjednici Politbiroa Centralnoga komiteta KPJ. Na toj je sjednici odlučeno da će se vodeći albanski komunisti periodično pozivati u Beograd na savjetovanja o važnim međupartijskim pitanjima. ${ }^{11}$ Jugoslavenski partijski vrh odmah po završetku rata nastavio je pomagati Albaniji. U novo, mirnodopsko doba najvažnija pomoć bijaše politička i diplomatska. Naime, glavni vanjskopolitički partner Albanije tada je bila upravo Jugoslavija. Stoga je Jugoslavija zastupala interese Albanije u 16 država jer Albanija nije imala diplomatske odnose s njima niti razvijenu diplomatsku mrežu. ${ }^{12}$ Jedina

\footnotetext{
8 Isto, 240.

9 HADALIN, Boj za Albanijo, 109; ŽIVOTIĆ, Jugoslavija, Albanija i velike sile, 127.

${ }^{10}$ HADALIN, Boj za Albanijo, 110; ŽIVOTIĆ, Jugoslavija, Albanija i velike sile, 127.

${ }^{11}$ HADALIN, Boj za Albanijo, 111; ŽIVOTIĆ, Jugoslavija, Albanija i velike sile, 128.

12 HADALIN, Boj za Albanijo, 111.
} 
međunarodna organizacija s kojom je Albanija izravno komunicirala bila je Uprava Ujedinjenih naroda za pomoć i obnovu (UNRRA), što je bilo vitalno važno zbog pomoći u hrani koju je ta organizacija pružala, uostalom, i Jugoslaviji. ${ }^{13}$ Pomoć Jugoslavije tada se sastojala od isporuka žita, koje su započele još u proljeće 1945. iako je i u samoj Jugoslaviji nedostajalo hrane. ${ }^{14}$ Pomoć se očitovala i u savjetodavnoj ulozi pri formiranju državne uprave te u organizaciji vojske. Naime, albanski komunistički vođe došli su na vlast u Tirani bez unaprijed formiranih ministarstava i drugih tijela javne vlasti. Komunistička partija Jugoslavije pomagala je izgrađivati albansku vojsku. ${ }^{15} \mathrm{I}$, što je najvažnije za međupartijske odnose, vrh KPJ udovoljio je albanskoj molbi da se iz Jugoslavije pošalju u Albaniju iskusni instruktori koji će ideološki pripremati albanske komuniste i pomagati im da se osposobe za rad u tijelima javne vlasti. ${ }^{16}$ Pomoć Jugoslavije u kulturi i prosvjeti, u sklopu koje su albanski studenti školovani u Jugoslaviji, dijelom i pomoću jugoslavenskih stipendija, bila je 1945. i 1946. jednako tako važna. Ipak, odnosi dviju komunističkih partija nisu tada, 1945., bili jako dobri. Velimir Stojnić kritizirao je vođe KPA, i to upravo u pogledu zanemarivanja partijskih kadrova i razvoja partijske organizacije i infrastrukture. Enver Hoxha pokazivao je sve veće nepovjerenje u njega i počeo ga isključivati sa sastanaka Politbiroa. ${ }^{17}$ Stojnić je u svojoj depeši Centralnom komitetu KPJ iz veljače 1946. nastavio kritizirati Albance da ne cijene dovoljno jugoslavensku vojnu i gospodarsku pomoć i da ne ispunjavaju svoje obveze prema Jugoslaviji. ${ }^{18} \mathrm{U}$ depeši Centralnom komitetu KPJ iz rujna 1945. Stojnić je prigovorio da albanski tisak piše o zbivanjima u Jugoslaviji neutralno ili suzdržano. I sam jugoslavenski vrh smatrao je da Stojnić pretjeruje i da je netaktičan, pa ga je smijenio s mjesta veleposlanika i u listopadu 1945. postavio na to mjesto Josipa Đerđu. ${ }^{19}$ Josip Đerđa, u Drugom svjetskom ratu na dužnostima u partizanskom pokretu u Hrvatskoj, bio je glavni predstavnik Jugoslavije u Albaniji do kolovoza 1946. godine. Vrlo brzo postao je i on kritičan prema albanskom komunističkom vrhu. Albansko vodstvo, prema njegovu mišljenju, nije vodilo borbu protiv građanske oporbe, koja se okupljala u Demokratskoj fronti, albanskoj inačici jugoslavenske Narodne fronte, i držao je da se vrh mora obračunati $s$ tom oporbom. ${ }^{20}$ Kao oportuniste u vrhu KPA Đerđa je označio dva političara. To su bili Sejfulla Maleshova i Omer Nishani. ${ }^{21}$ Maleshova je bio zastupnik vezivanja Albanije ne samo uz Jugoslaviju nego i uz neke zapadne zemlje, prvenstveno Italiju. Osim toga nije smatrao da se treba obračunavati s

\footnotetext{
13 Isto.

14 ŽIVOTIĆ, Jugoslavija, Albanija i velike sile, 153.

15 Isto, 143-146.

16 Isto, 146-147.

${ }^{17}$ HADALIN, Boj za Albanijo, 114-115.

18 ŽIVOTIĆ, Jugoslavija, Albanija i velike sile, 129.

${ }^{19}$ HADALIN, Boj za Albanijo, 115; ŽIVOTIĆ, Jugoslavija, Albanija i velike sile, 129.

${ }^{20}$ HADALIN, Boj za Albanijo, 116-117.

${ }^{21}$ Isto, 116; ŽIVOTIĆ, Jugoslavija, Albanija i velike sile, 130-131.
} 
građanskom oporbom koja se okupljala u Demokratskoj fronti. ${ }^{22}$ Takva politika ubrzo ga je učinila nepodobnim u vodstvu KPA. U veljači 1946., na Petom plenumu Centralnoga komiteta KPA, isključen je iz Politbiroa i Centralnoga komiteta KPA. ${ }^{23} \mathrm{Na}$ temelju Đerđine depeše od 16. prosinca 1945. upućene Josipu Brozu Titu Životić smatra da su na obračun s Maleshovom i ostalim prozapadnim političarima jako utjecali jugoslavenski pritisci, kao i uvjeravanja o daljnjoj pomoći. ${ }^{24}$ On, kao i Hadalin, na temelju izvora i literature interpretira degradaciju Maleshove tako što su Enver Hoxha i Koçi Xoxe privremeno sklopili pakt na zajedničkom interesu za odstranjivanje prozapadnih oportunista iz vrha albanske države i KPA. ${ }^{25}$ Koçi Xoxe bio je do 1948. član Politbiroa i Centralnoga komiteta KPA te ministar unutarnjih poslova. I Hoxha i Xoxe tada su, u veljači 1946., mislili da treba produbiti gospodarsku suradnju s Jugoslavijom. Xoxe je bio glavni zagovornik projugoslavenske linije u vrhu KPA.

S druge strane, prosovjetska usmjerenost albanskoga političkog i državnog vrha zabilježena je u dokumentima već od samoga početka 1946. godine. Čim je Sovjetski Savez u prosincu 1945. uspostavio diplomatske odnose s Albanijom, počela su se javljati uvjerenja da se Albanci više vole povezivati sa sovjetskim stručnjacima nego s jugoslavenskima. Tako je jugoslavenski vojni ataše Đuro Medenica izvješćivao Centralni komitet KPJ i Ministarstvo obrane FNRJ da je sve veća orijentacija Albanaca na sovjetske stručnjake posljedica albanskoga nezadovoljstva lošim jugoslavenskim kadrovima te straha od moguće jugoslavensko-albanske federacije u kojoj bi Albanija bila samo sedma jugoslavenska republika, a na taj bi način Enver Hoxha bio stalno podčinjen Josipu Brozu Titu, generalnom sekretaru Centralnoga komiteta KPJ, vrhovnom zapovjedniku NOVJ-a i predsjedniku Vlade FNRJ. ${ }^{26}$

U ožujku 1946. na sjednici Politbiroa Centralnoga komiteta KPJ odlučeno je da se Envera Hoxhu pozove u državnički posjet u Beograd. ${ }^{27}$ Hoxha, koji se prije u razgovorima s Đerđom dvoumio u svezi s posjetom Beogradu, sada je prihvatio poziv. Posjet je nakon Đerđine depeše Titu od 29. ožujka 1946. planiran za sredinu travnja. ${ }^{28}$ Zatim je odgođen za kraj svibnja. Toga je puta posjet odgodio Tito. Na kraju svibnja i početkom lipnja 1946. Tito je boravio s državnom delegacijom u posjetu Moskvi. Sa Staljinom je, među ostalim, razgovarao o albanskom vodstvu. Kada se uvjerio da Staljin ima distancu prema Albaniji i vrhu KPA i da se ne želi miješati u jugoslavensku državnu i partijsku politiku prema Albaniji, Tito je konačno pozvao Envera Hoxhu u posjet Beogradu 23. lipnja 1946. godine. ${ }^{29}$

\footnotetext{
${ }^{22}$ HADALIN, Boj za Albanijo, 116.

${ }^{23}$ Isto, 117; ŽIVOTIĆ, Jugoslavija, Albanija i velike sile, 131.

${ }_{24}$ ŽIVOTIĆ, Jugoslavija, Albanija i velike sile, 131.

${ }^{25}$ Isto, 131-132; HADALIN, Boj za Albanijo, 117.

${ }^{26}$ HADALIN, Boj za Albanijo, 124.

27 Isto.

28 ŽIVOTIĆ, Jugoslavija, Albanija i velike sile, 133.

29 Isto, 134, 178-179; HADALIN, Boj za Albanijo, 124-125.
} 
Intenzivna gospodarska suradnja Federativne Narodne Republike Jugoslavije i Narodne Republike Albanije

Rezultat Hoxhina posjeta Beogradu bio je nastanak tijesne suradnje dviju država na gospodarskom planu. No, najprije je uglavljen sporazum o tijesnom vezivanju dviju država. Kao uzor tom sporazumu služio je Ugovor o prijateljstvu, uzajamnoj pomoći i poslijeratnoj suradnji između Jugoslavije i Sovjetskoga Saveza zaključen 11. travnja 1945. u Moskvi i proglašen 12. lipnja. ${ }^{30} \mathrm{U}$ čl. 1. Ugovora između Jugoslavije i Sovjetskoga Saveza stoji da jedna zemlja pomaže drugoj do kraja rata protiv Hitlerove Njemačke. Članak 2. predviđa da će u poslijeratnom razdoblju jedna zemlja pomagati drugoj u eventualnom novom ratu s Njemačkom i bilo kojom drugom zemljom koja bi se pridružila Njemačkoj. Po čl. 4., obje zemlje obvezuju se da neće ulaziti u saveze uperene protiv jedne od tih dviju zemalja. Tito i Hoxha dogovorili su tijekom susreta u Beogradu Ugovor o prijateljstvu i uzajamnoj pomoći između FNRJ i Narodne Republike (NR) Albanije, koji je potpisan u Tirani 9. srpnja 1946. i stupio na snagu zakonom od 26. srpnja. ${ }^{31}$ Jugoslavensko-albanski ugovor specifičan je u odnosu na prethodno spomenuti po tome što u čl. 3. stoji da ako bi jednu od strana ugovornica bilo tko napao, druga će joj strana pružiti pomoć, i to vojnu i svaku drugu. Nije se stalo samo na tom međusobnom ekskluzivnom osiguranju. Dana 1. srpnja sklopljen je Sporazum o privrednoj suradnji između FNRJ i NR Albanije. Vladimir Dedijer tumači taj sporazum: „Sporazum predviđa da će Vlada FNRJ odobriti NR Albaniji kredit za nabavku mašina i oruđa radi kompletiranja i izgradnje njene industrije za proizvodnju artikala široke potrošnje; da će Vlada FNRJ ukazati NR Albaniji tehničku pomoć u svim granama industrije i u poljoprivredi odašiljanjem jugoslovenskih stručnjaka, davanjem tehničkih informacija, izradom projekata i druge dokumentacije, kao i obukom u Jugoslaviji albanskih radnika i njihovim upoznavanjem s radom i funkcionisanjem naučnih i tehničkih ustanova i preduzeća FNRJ. Sporazum, pored toga, predviđa obrazovanje mešovitih albansko-jugoslovenskih društava radi obnove i povećanja proizvodnih mogućnosti Albanije na principu pariteta $s$ jednakim učešćem u osnovnom kapitalu i jednakim učešćem u upravi društava. U duhu ovog sporazuma sklopljen je 27 novembra 1946 godine Ugovor o usklađivanju privrednih planova, carinskoj uniji i izjednačenju valute i u njemu se predviđa da radi usklađivanja privrednih planova 'Vlada FNRJ pruži Vladi NRA putem uvoza u NR Albaniju robu i materijal namenjen privrednoj obnovi na način i u srazmeri koji će biti predviđeni privrednim planovima, svu neophodnu pomoć za ostvarenje albanskog privrednog plana, kao i da osigura promet robe koja je neophodna za održavanje albanskog leka na paritetu jugoslovenskog dinara.' - što znači praktično preuzimanje obaveze za izvršenje

\footnotetext{
${ }^{30}$ Službeni list Demokratske Federativne Jugoslavije (Beograd), 40 (1945), 341-344.

${ }^{31}$ Službeni list Federativne Narodne Republike Jugoslavije (Beograd), 60 (1946), 693; DEDIJER, Jugoslovensko-albanski odnosi, 142; HADALIN, Boj za Albanijo, 136; ŽIVOTIĆ, Jugoslavija, Albanija i velike sile, 138-139.
} 
albanskog privrednog plana." 32 Na temelju Sporazuma o privrednoj suradnji sklopljeno je do kraja godine još dvadesetak sporazuma i protokola u oblasti gospodarskih odnosa dviju zemalja. Albanskim komunistima sve je to bilo nužno jer albansko gospodarstvo od završetka rata nije moglo stati na vlastite noge. U proračunskoj godini 1945./1946. pokazao se golemi vanjskotrgovinski i proračunski deficit, a i za sljedeću godinu perspektive su bile vrlo slabe. Proračunski deficit iznosio je, po jugoslavenskim procjenama, oko $40 \%{ }^{33} \mathrm{~S}$ druge strane u Albaniju su već sredinom 1945. stigli i jugoslavenski gospodarski stručnjaci. Dakle, nisu samo vojni stručnjaci savjetovali Albance 1945. godine. Prvi zadatak gospodarskih stručnjaka bila je procjena mogućnosti izgradnje mreže željezničkih pruga u Albaniji, zemlji koja 1945. nije imala nijednu željezničku prugu. ${ }^{34}$

U vrijeme iznimnog jačanja gospodarske suradnje Jugoslavije i Albanije u Albaniju dolazi Savo Zlatić, izaslanik Centralnoga komiteta KPJ pri Centralnom komitetu KPA. Zlatić je prije Drugoga svjetskog rata studirao medicinu i bio član KPJ. U ratu je vodio partizansku bolnicu na Petrovoj gori, a po završetku rata bio je ministar. Poslan je u Albaniju da bi jugoslavenski partijski vrh imao bolje veze s albanskim partijskim vrhom i dobivao izvješća o svim aspektima situacije u Albaniji - političkom, gospodarskom, kulturnom i vojnom. ${ }^{35}$ Zlatić je nastavio s miješanjem u odnose u partijskom vodstvu KPA, slično kako su prije radili Stojnić i Đerđa. U svojoj je osobi utjelovljavao politiku jugoslavenskoga političkog vrha i prema vodstvu KPA i prema Albaniji općenito. Samo nekoliko tjedana nakon dolaska Zlatić u pismu Centralnom komitetu KPJ od 26. kolovoza 1946. prepoznaje dvije struje u Politbirou Centralnoga komiteta KPA. ${ }^{36}$ U jednoj su Enver Hoxha i Nako Spiru, a u drugoj Koçi Xoxe i Pandi Kristo. Spiru je tijekom rata bio omladinski partijski dužnosnik, a nakon rata ministar industrije. Zlatić je istaknuo da Spiru često govori ono što Hoxha misli. Stekao je dojam da i odnosi u Centralnom komitetu nisu zdravi. O kadrovskoj politici raspravljalo se satima, a pritom je bio uvjerenja da je tu bitno samo hoće li na neko mjesto doći osoba bliska Hoxhi ili Xoxeu.

Zlatić je u notesu vodio bilješke o albanskoj problematici. U njima je 23. rujna zapisao da je za vrijeme boravka Envera Hoxhe u Parizu prisustvovao svim sjednicama Politbiroa. ${ }^{37}$ Pretresala su se uglavnom gospodarska pitanja, ali bez dnevnoga reda, pa je svaki član govorio o raznim pitanjima, od kojih se neka i nisu ticala gospodarstva. Sjednice su trajale i po osam sati, a da se na njima ništa nije zaključilo. Zlatić je primijetio da i 15 dana nakon prve sjednice nema nikakvih zaključaka Centralnoga komiteta o gospodarskim pitanjima ili

\footnotetext{
${ }^{32}$ DEDIJER, Jugoslovensko-albanski odnosi, 173-174.

${ }^{33}$ HADALIN, Boj za Albanijo, 143.

${ }^{34}$ Isto, 147; ŽIVOTIĆ, Jugoslavija, Albanija i velike sile, 156.

35 ŽIVOTIĆ, Jugoslavija, Albanija i velike sile, 140; HADALIN, „Naš človek v Tirani”, 497-516.

36 ŽIVOTIĆ, Jugoslavija, Albanija i velike sile, 141; HADALIN, „Naš človek v Tirani”, 505.

${ }^{37}$ HR-HDA-1798, OF Savo Zlatić, kut. 7, Notes s rukopisnim zabilješkama o albanskoj problematici.
} 
o jednom tako hitnom pitanju kao što je organizacija jesenske sjetve. Zlatić je petoga i šestoga člana Politbiroa, Bedrija Spahiua i Tuka Jakovu, okarakterizirao kao osobe koje ne pokazuju mnogo volje za rad i drže se postrani. Hoxha se požalio Zlatiću da postoji čitav niz sekretara većih partijskih organizacija koji ga uopće ne poznaju jer veze Politbiroa s partijskim organizacijama u svojim rukama drži Xoxe. Zlatić zaključuje da Politbiro i Centralni komitet moraju postati operativno rukovodstvo koje će kolektivno odlučivati o svim pitanjima umjesto da se svatko bavi svojim resorom i ne polaže račune o svojem radu partijskom forumu. Zlatić je zapisao i da je albanskim drugovima prenio iskustva iz Centralnoga komiteta KP Hrvatske, gdje se odluke donose kolektivno.

Samo dva dana poslije, 25. rujna, Hoxha je pozvao Zlatića i rekao mu da će s vremenom iz Politbiroa otpasti Spahiu, Jakova i Kristo. ${ }^{38} \mathrm{O}$ tome je Zlatić pisao u izvješćima Centralnom komitetu KPJ 7. i 12. listopada. Budući da mu je Hoxha govorio da bi u Politbiro trebalo kooptirati čak pet novih članova - pa bi ih umjesto šest bilo jedanaest - Zlatić mu je odgovorio po stavkama: 1) pitanje stvaranja homogenoga i zdravoga Politbiroa ne može se riješiti pukom kooptacijom, nego to iziskuje dugotrajni rad; 2) uzimanje najednom tih pet ljudi znači izmjenu Politbiroa, a situacija nije odgovarajuća jer bi to imalo odjeka u čitavoj KPA; 3) bolje je uzeti manje ljudi, a pratiti rad ostalih; 4) ne uzimati u Politbiro ljude koji čak nisu članovi Centralnoga komiteta, nego ih treba postupno uzdizati. Naravno, Hoxhina zamisao o kooptaciji bila je u svezi s namjerom da se Xoxea izgura iz Politbiroa i marginalizira. Tako su se Zlatić i Xoxe našli na jednoj strani, a Hoxha na drugoj. Napravljen je kompromis tako što su u Politbiro kooptirana samo tri nova člana. Među njima je Hysni Kapo bio Hoxhin favorit, Kristo Themelko bio je prihvatljiv svim grupama, a Gogo Nushi imao je potporu Xoxea. Krajem listopada Zlatić je tražio i dobio dozvolu da ode u Beograd na konzultacije, prvenstveno zbog te situacije u Politbirou Centralnoga komiteta KPA. U Beogradu se u isto vrijeme nalazio i Nako Spiru zbog priprema o usklađivanju gospodarskih planova, kao i Koçi Xoxe. O rezultatima toga savjetovanja o međupartijskim pitanjima u literaturi nema informacija. Ipak, sudeći po zaključcima Plenuma Centralnoga komiteta KPA iz prosinca 1946., međupartijska trvenja nisu utjecala na osnovnu liniju KPA. Plenum je zaključio da su gospodarski sporazumi potpisani s FNRJ stvorili osnovu za razvoj albanskoga gospodarstva i da su logična posljedica Sporazuma o privrednoj suradnji iz srpnja. ${ }^{39}$ I na planu vojne suradnje te suradnje u policijskim i obavještajnim pitanjima tijekom 1945. i 1946. FNRJ je pružala pomoć. Jugoslavenska vojska slala je oružje, streljivo, inženjerijsku opremu i opremu za vezu. ${ }^{40} \mathrm{~K}$ tome je ideološki obučavala albansku vojsku. Koçi Xoxe molio je u svojstvu ministra unutarnjih poslova preko veleposlanika Đerđe

\footnotetext{
${ }^{38}$ HR-HDA-1798, OF Savo Zlatić, kut. 7, Notes s rukopisnim zabilješkama o albanskoj problematici; HADALIN, Boj za Albanijo, 139-140; ŽIVOTIĆ, Jugoslavija, Albanija i velike sile, 141142.

39 ŽIVOTIĆ, Jugoslavija, Albanija i velike sile, 142.

${ }^{40}$ Isto, 163-164.
} 
od jugoslavenskoga ministra unutarnjih poslova Aleksandra Rankovića razvoj intenzivnije suradnje u policijskim i obavještajnim pitanjima. Posebno se to odnosilo na formiranje albanskih snaga Narodne obrane, koje su bile zamišljene po uzoru na jugoslavenski Korpus narodne obrane, korpus s vojnim i policijskim obilježjima zadužen za borbu protiv antikomunističkih bandi i drugih neprijatelja nove vlasti. ${ }^{41}$

Savo Zlatić, kao i Đerđa, neposredno je komunicirao s Aleksandrom Rankovićem, članom Politbiroa Centralnoga komiteta KPJ, ratnim članom Vrhovnoga štaba NOVJ-a i ministrom unutarnjih poslova FNRJ. Kao što smo vidjeli, jedna od Zlatićevih zadaća bila je kadrovska politika u albanskom Politbirou i Centralnom komitetu. Hadalin ide tako daleko da na temelju Zlatićevih depeša zaključuje da je zapravo Ranković tada upravljao Albanijom. ${ }^{42}$ Kako bilo da bilo, iz Zlatićeva osobnoga fonda vidljivo je da se mnogo bavio i gospodarskim pitanjima. Dana 10. veljače 1947. napisao je Centralnom komitetu KPJ koncept izvješća u kojem je tvrdio da je gospodarski položaj Albanije iznimno težak i da je albansko rukovodstvo napravilo jedini mogući logični potez time što je krenulo u gospodarsko jedinstvo s Jugoslavijom. ${ }^{43}$ Pritom je rekao da su protivnici albanskih komunističkih vlasti to iskoristili da bi širili parole da su ugovori s FNRJ isti put koji je Albanija prolazila s Italijom prije Drugoga svjetskog rata, dakle stvaranje polukolonijalne ovisnosti. Protivnici su govorili da će se Albanija na taj način politički uključiti u FNRJ i da će u tom odnosu biti oštećena i politički i gospodarski. Deset dana poslije Zlatić primjećuje u izvješću Centralnom komitetu KPJ da su plaće radnika i službenika jako niske, da seljaci ne mogu kupovati industrijske proizvode, pa se sve više okreću autarkičnom i tradicionalnom privređivanju, kao i da je trgovina spora i neučinkovita, a financijski sustav nesređen. ${ }^{44} \mathrm{U}$ izvješću Centralnom komitetu KPJ od 8. travnja Zlatić je iznio da je zbog svih tih gospodarskih teškoća zahtijevao od albanskih političkih rukovoditelja da se odmah prijeđe na novi sustav cijena i novi način raspodjele plaća i nadnica te da se ojača trgovina i realno postavi gospodarski plan. ${ }^{45}$

Od sačuvanih Zlatićevih zabilješki tijekom proljeća najvažnija je ona o razgovoru s ministrom Gogom Nushijem datirana s 31. svibnja i 1 . lipnja. ${ }^{46} \mathrm{U}$ njima se ukratko skicira sva raznolikost razgovora o organiziranju trgovine, trgovačke mreže i odnosa između detaljista, grosista, potrošača i zadruga.

\footnotetext{
${ }^{41}$ Isto, 168.

${ }^{42}$ HADALIN, „Naš človek v Tirani”, 506.

${ }^{43}$ HR-HDA-1798, OF Savo Zlatić, kut. 6, Izvještaji i depeše CK.

${ }_{44}$ ŽIVOTIĆ, Jugoslavija, Albanija i velike sile, 224.

45 Isto.

${ }^{46}$ HR-HDA-1798, OF Savo Zlatić, kut. 6, Izvještaji CK, zabilješke o razgovorima s albanskim dužnosnicima.
} 


\section{Kriza u odnosima}

Prema Hadalinu, prva kriza u odnosima FNRJ i Albanije izbila je u kasno proljeće 1947., kada je jugoslavenska strana odbacila albanski gospodarski plan i iznijela svoje mišljenje, na što je prema Ugovoru o usklađivanju privrednih planova imala pravo. ${ }^{47}$ Petogodišnji gospodarski planovi bili su jedan od najvažnijih elemenata vođenja gospodarstva u socijalističkim zemljama. Drugi važan predmet spora u odnosima dviju država i partija bio je jugoslavenski kredit Albaniji od 2 milijarde dinara. ${ }^{48}$ Taj je kredit iznosio čak 56,73 $\%$ albanskoga proračuna. Albanski komunisti nisu se usuđivali izići u javnost s podacima o stvarnom opsegu jugoslavenske pomoći jer su se plašili reakcije javnosti. Nije im bilo zgodno reći da pomoć iznosi više od polovice albanskoga godišnjeg proračuna. ${ }^{49}$

Tijekom 1947. Nako Spiru profilirao se kao vođa antijugoslavenske i prosovjetske struje u albanskom komunističkom vodstvu. ${ }^{50}$ On je u travnju 1947. otišao u Moskvu, pri čemu je vodio kulturno-prosvjetnu delegaciju i uspio isposlovati jačanje sovjetske prisutnosti i utjecaja u Albaniji tako što će dolaziti sovjetski profesori, što će se povećati broj albanskih studenata na sovjetskim sveučilištima i što će opskrba udžbenicima iz Sovjetskoga Saveza i razne izložbe postati učestale. ${ }^{51} \mathrm{U}$ srpnju je sam Enver Hoxha otišao u posjet Sovjetskom Savezu. Prema nekim izvorima, Staljin je već tada izrazio Hoxhi nezadovoljstvo jugoslavenskom politikom prema Albaniji kao previše pokroviteljskom, a prema drugima je Staljin tada bio suzdržan u svezi s Hoxhinim žalbama da se jugoslavenska Vlada ne trudi dovoljno i da nije zainteresirana za razvoj gospodarskih odnosa s Albanijom. ${ }^{52}$ Hoxha svojim posjetom Moskvi nije ostvario neke veće rezultate poput znatno veće sovjetske materijalne i kulturne pomoći. Međutim, ipak su jugoslavenski predstavnici nakon posjeta stekli dojam da se Albanija sve više okreće prema Sovjetskom Savezu. ${ }^{53}$

U ljeto i početkom jeseni 1947. produbljivala se kriza između dvije države i partije. Spiru je odbijao jugoslavenske prigovore da je albanski gospodarski plan potpuno nerealan. U rujnu je Marko Perović, član Koordinacijske komisije, tijela zaduženog za vođenje i nadzor jugoslavensko-albanske gospodarske suradnje, i službeno predao negativno mišljenje Vlade FNRJ o albanskom planu. Albanski ministar trgovine Kiço Ngjela tada je optužio FNRJ za neurednu i premalenu opskrbu robom, pomanjkanje stručne radne snage iz FNRJ i loše poslovanje mješovitih društava. Perović je uzvratio protuoptužbama da Albanci ne isporučuju sirovu naftu i bitumen te da su neozbiljni i da loše vode

\footnotetext{
${ }^{47}$ HADALIN, Boj za Albanijo, 154-155.

${ }^{48}$ Isto, 148; ŽIVOTIĆ, Jugoslavija, Albanija i velike sile, 233-234.

49 ŽIVOTIĆ, Jugoslavija, Albanija i velike sile, 226.

${ }^{50}$ Isto; HADALIN, Boj za Albanijo, 155-158.

${ }^{51}$ ŽIVOTIĆ, Jugoslavija, Albanija i velike sile, 249.

${ }^{52}$ Isto, 253-254; HADALIN, Boj za Albanijo, 155-156.

${ }^{53}$ HADALIN, Boj za Albanijo, 158.
} 
knjigovodstvo, a pritom nije smatrao da Jugoslaveni ne ispunjavaju svoje obveze. ${ }^{54}$

Dobar prikaz loših odnosa donose daljnja izvješća i bilješke Save Zlatića. U izvješću iz Tirane od 10. lipnja 1947. u obliku koncepta Zlatić se dotaknuo pitanja odnosa Jugoslavena s Albancima, sindikalnoga i kulturno-prosvjetnoga rada i pitanja organizacije KPJ u Albaniji. ${ }^{55} \mathrm{Tu}$ saznajemo da je u Albaniji više-manje stalan broj od oko 700 Jugoslavena, u čiji sastav ulaze omladinska brigada, „naše ljudstvo” na pruzi i vojni instruktori. Vidi se na što je FNRJ stavila naglasak - preko 500 ljudi je na pruzi. Ostatak, nešto više od 100 ljudi, nalazi se u Tirani, a samo nekoliko desetaka ljudi raštrkano je diljem zemlje. Ta mala grupa ljudi, prema Zlatićevu mišljenju, znatno pomaže u ostvarenju albanskoga plana izgradnje. Jugoslaveni kao savjetnici u ministarstvima i vojsci pružili su veliku pomoć. No, već u sljedećem odlomku tenkovski instruktori označeni su kao slaba karika u lancu. Bez iznošenja dokaza o tome, Zlatić predlaže zamjenu te ekipe drugom. Iznimno važno pitanje tada je bila izgradnja prve željezničke pruge u Albaniji, Drač - Elbasan. Nažalost, to je i neuralgično pitanje. Grupa od oko 500 Jugoslavena na pruzi, po Zlatićevu mišljenju, jako je šarolika i neki od njih ostavljaju loš dojam na Albance. Dvojica čak izražavaju neprijateljski stav prema vlastima i harangiraju protiv Partije. Zlatić dalje kaže da bi važnu ulogu u Albaniji mogli imati profesori iz FNRJ. U cijeloj zemlji ima ih jedanaest. Preko škola i tečajeva dolaze u dodir s oko tisuću Albanaca. Zlatić se žali da su profesori, osobito oni iz Hrvatske i Srbije, često politički slabi. Zato je u dogovoru s Agitpropom Centralnoga komiteta KPJ i Komitetom za škole i nauku odlučeno da se profesore koji su bili na radu godinu dana vrati i u novoj školskoj godini pošalju drugi. Kakve je to osjećaje moglo izazivati kod Albanaca može se samo nagađati. Zlatić izvješćuje da je prema direktivama Centralnoga komiteta KPJ zajedno sa suradnicima organizirao kampanju, prilikom koje su bili organizirani sastanci partijskih ćelija i sindikalnih organizacija. Na kraju, problem je bio i u tome što se neki profesori teško mogu riješiti superiornoga stava prema Albancima i nekonstruktivne kritike.

U izvješću Centralnom komitetu KPJ od 1. srpnja 1947. Zlatić iznosi primjedbe za predstojeće razgovore u Beogradu. On tu prvi put priznaje da je još u vrijeme Spiruova boravka u Moskvi u razgovoru s Xoxeom ustvrdio da postoje dvije linije u gospodarskom sektoru. ${ }^{56}$ Naime, jedna je bila ona dogovorena s FNRJ, a druga ona koja je postojala u stvarnosti. A stvarnost je bila takva da se otezalo, da se raspoloživi kadar nije uopće mobilizirao na rješavanju gospodarskih pitanja i da su prve pripreme obavljene tek početkom svibnja na intervenciju jugoslavenskih predstavnika. Zlatić je uočio da je Spiru ključ za rješavanje gospodarskih problema Albanije vidio u ispunjavanju obveza FNRJ. Stekao je dojam da se željelo pokazati slabost Jugoslavije i

\footnotetext{
${ }^{54}$ Isto, 158-159; ŽIVOTIĆ, Jugoslavija, Albanija i velike sile, 239.

${ }^{55}$ HR-HDA-1798, OF Savo Zlatić, kut. 6, Izvještaji i depeše CK.

${ }^{56}$ HR-HDA-1798, OF Savo Zlatić, kut. 6, Izvještaji i depeše CK.
} 
njezinu nemoć u pomaganju Albaniji. Iz toga se onda vodila politika da se od FNRJ „utjera” što više, a da se istovremeno što više očuva gospodarska samostalnost i traži suradnja i s drugim zemljama. Po Zlatiću, i albanski pregovori sa Sovjetskim Savezom o isporuci traktora i njihovi kontakti s Mađarskom i Švicarskom vodili su u tom smjeru. On je osjećao da su se takvi stavovi prenosili i na srednji albanski kadar koji je radio u ministarstvima zaduženima za gospodarstvo, pa se i među tim ljudima počela javljati neka rezerviranost prema Jugoslaviji i hlađenje odnosa. Zlatić je razmišljao o korijenima takve linije i zaključio da je tu riječ o strahu od Jugoslavije, strahu kojega ima i kod samoga Envera Hoxhe. Uočio je da u Albanaca postoje nacionalni osjećaji u malograđanskom smislu i da upravo ti osjećaji smetaju da se bez rezerve gleda na novu Jugoslaviju. Zaključio je da su tijesni gospodarski odnosi, umjesto da zbliže dvije zemlje i partije, doveli do zahlađenja međusobnih odnosa, što se po njemu odnosilo samo na određeni broj ljudi koji su vodili gospodarstvo, a ne i na radne mase, koje su većinom bez rezerve gledale na Jugoslaviju. Otkud Savi Zlatiću takav i toliko hrabar zaključak da široki slojevi naroda gledaju „bez rezerve” na Jugoslaviju? Sada počinje drugarska samokritika. Naveo je da su jugoslavenski kadrovi došli s velikim zakašnjenjem, posebno u mješovita društva, pa je tako Društvo za gradnju električnih centrala počelo s radovima na hidrocentrali kod Tirane tek 1. srpnja. Tu je iznio važnu napomenu da je rok ovisio isključivo o FNRJ budući da Albanci sudjeluju samo s nekvalificiranom radnom snagom. Hadalin tumači da projekt centrale nije bio predviđen u jugoslavenskom petogodišnjem planu i slijedom toga su iskrsnule teškoće i s dobavom materijala jer ga je i u FNRJ bilo premalo. Hidrocentrala nije dovršena ni do prekida odnosa FNRJ i NR Albanije, pa su posao poslije završili sovjetski stručnjaci. ${ }^{57}$ Zlatić je dalje spomenuo da su kasnili i stručnjaci za željeznice iz FNRJ, kao i specijalisti u Društvu za rude i stručnjaci u Društvu za naftu. Ostaviti vojnu misiju Jugoslavije da tijekom čitave godine spadne na jednoga čovjeka, o čemu je izvješćivao vojni ataše FNRJ u Tirani 5. lipnja 1946., sigurno izgleda podcjenjivački. Naime, ako su Jugoslaveni, među ostalim, namjeravali Albancima pomagati i u izgradnji vojske, onda takav podcjenjivački odnos zacijelo dolazi sa samoga vrha države i KPJ. Edvard Kardelj, član Vrhovnoga štaba NOVJ-a u ratu te član Politbiroa i Centralnoga komiteta KPJ, rekao je na sjednici Politbiroa Centralnoga komiteta KPJ 1. ožujka 1948. da „... Albaniju treba čvrsto držati, jer smo mnogo uložili i ona je za nas važna”. Dodao je i: „Imamo pravo da kontrolišemo šta Albanci rade, kakve ugovore sklapaju." ${ }^{58}$ U svojem izvješću Zlatić je nastavio sa samokritikom. Prikazao je negativno i Spirua. Za njega je Spiru prije svega loš čovjek jer namjerno svaljuje krivnju na Jugoslaviju u pitanju rješavanja problema albanskoga gospodarstva. Iz literature i izvora može se vidjeti da je Spiru postao izrazito prosovjetski usmjeren. Smatrao je da je jugoslavenska pomoć loša i da je Sovjetski Savez vještiji i pravičniji u pružanju pomoći. To je Zlatića sme-

\footnotetext{
${ }^{57}$ HADALIN, Boj za Albanijo, 150-151.

${ }^{58}$ PETRANOVIĆ, Zapisnici sa sednica Politbiroa Centralnog komiteta KPJ, 240.
} 
talo budući da je on jugoslavensku pomoć ocijenio golemom. ${ }^{59}$ Zlatić je usto pretjerano optimistično vjerovao da će provedba gospodarskih mjera odmah znatno popraviti stanje u zemlji. Uza sve provođenje gospodarskih mjera, u Albaniji je zbog neuspjeha u uzgoju žitarica 1948. prijetila glad, pa je molila hitnu pomoć. ${ }^{60}$ Zlatić je ponekad samo prešao preko Spiruovih primjedbi, kao kada je Spiru rekao da se boji kako će seljaštvo reagirati na velike gospodarske promjene u zemlji.

Zlatić je sastavio još jedno izvješće sredinom kolovoza, pisano pisaćim strojem, ali s mnogo ispravaka. Vjerojatno je riječ o nacrtu izvješća koji je ostao u njegovu fondu. Tu se na drugi način pozabavio spomenutim razgovorima i suradnjom s albanskim partijskim vrhom u prvoj polovini 1947. godine. ${ }^{61}$ Iz njega je vidljivo da se Zlatić osjeća opstruirano od Politbiroa Centralnoga komiteta KPA, i to najviše od Spirua, zatim od Hoxhe, i najmanje od Koçija Xoxea. Za vrijeme svoje misije u Albaniji on je raspravljao s albanskim partijskim vrhom o gospodarskim pitanjima te davao savjete i zahtijevao određeno postupanje u vođenju gospodarstva. Sada je došlo i do razilaženja u stavovima. Naime, Zlatić se razišao u stavovima s Politbiroom Centralnoga komiteta KPA o izjednačenju albanske valute leka s jugoslavenskim dinarom i učvrstio svoje mišljenje o dvije linije u albanskom vrhu u svezi s gospodarstvom. Za njega je odgađanje predviđene promjene tečaja bilo politika samoga Centralnoga komiteta KPA. Zlatić se ponovo latio i samokritike. Ovaj je put primijetio da Društvo za naftu organizacijski stoji jako loše i bori se $s$ velikim poteškoćama jer Jugoslaveni teško mogu dati potrebni kadar budući da ni sami nemaju potrebne specijaliste. Loša je situacija bila i u raznim drugim područjima. U prilog Zlatićevim tvrdnjama išla je i analiza nastala 1948. za potrebe Centralnoga komiteta KPJ. U njoj je naglašeno da je isporuka materijala iz FNRJ kasnila, i da još kasni u vrijeme pisanja analize. Autori analize uočili su da se među jugoslavenskim stručnjacima u Albaniji našlo ljudi koji se nisu dovoljno zalagali. Mnogi od njih dolazili su na samostalniji rad od onoga koji su obavljali u FNRJ, stoga nisu bili dorasli zadatku. Upravo takve albanske prigovore na stručnjake iz FNRJ može se naći u izvorima i literaturi. Sastavne dijelove tvornice šećera planiralo se isporučiti u prvoj polovini 1947., a oni su, prema analizi, isporučeni tek u ožujku 1948. godine. ${ }^{62}$ Tada je slijedilo montiranje tvornice, a potrebne dijelove tek je trebalo nabaviti iz inozemstva. Tvornica ribljih konzervi isporučena je u listopadu 1947., a tehnički rukovoditelj u poslu montiranja upućen je u Albaniju tek u proljeće 1948. godine. U literaturi ta tema nije obrađena.

Do studenoga 1947. stanje u odnosima Jugoslavena i Albanaca nastavilo se pogoršavati. Zlatić je ukratko zapisao sukobe i odnose između Albanaca i

\footnotetext{
59 ŽIVOTIĆ, Jugoslavija, Albanija i velike sile, 184-189.

${ }^{60}$ PETRANOVIĆ, Zapisnici sa sednica Politbiroa Centralnog komiteta KPJ, 626.

${ }^{61}$ HR-HDA-1798, OF Savo Zlatić, kut. 6, Izvještaji i depeše CK.

${ }^{62}$ PETRANOVIĆ, Zapisnici sa sednica Politbiroa Centralnog komiteta KPJ, 633-635.
} 
Jugoslavena od srpnja do listopada. ${ }^{63}$ Tako su se loši odnosi vodstva KPJ i KPA sve više prelijevali na odnose u poduzećima, ustanovama i na gradilištima.

Zlatić je u studenom razgovarao s Hoxhom o primjedbama Centralnoga komiteta KPJ na račun albanskoga vodstva. U literaturi i izvorima te primjedbe, sačinjene vjerojatno u listopadu ili početkom studenoga, nisu eksplicirane. Naglo odstranjivanje Spirua iz Politbiroa i njegovo samoubojstvo objašnjavaju se time da je njegov protivnik Koçi Xoxe iskoristio povoljan trenutak i mobilizirao projugoslavensku grupu unutar Politbiroa. ${ }^{64}$ Zapravo, tu se kao arbitar pojavio Enver Hoxha i tako presudio Spiruu. U razgovoru sa Zlatićem 16. studenog, samo nekoliko dana prije Spiruova pada, Xoxe je ukratko prikazao Hoxhinu taktiku. Hoxha se, naime, držao „nevjerojatno kolebljivo. Ili bi likvidirao Naku, ili bi ga najodlučnije branio”. ${ }^{65}$ Kada je Hoxha razgovarao s Xoxeom, onda bi se uglavnom složio s njim. Kada bi razgovarao sa Spiruom, promijenio bi mišljenje i složio se sa Spiruom.

\section{Kratka obnova jedinstva}

Nakon Spiruova samoubojstva projugoslavenska struja u KPA pripremala se za Osmi plenum Centralnoga komiteta KPA. Koçi Xoxe i njegovi ljudi uspjeli su pobijediti na plenumu, koji je održan na prijelazu iz veljače u ožujak 1948. godine. U zaključnoj rezoluciji Osmoga plenuma priznata je važnost gospodarskoga jedinstva FNRJ i NR Albanije. ${ }^{66}$ To jedinstvo, kao i svi oblici suradnje koji iz njega proizlaze, izričito je istaknuto kao glavni okvir koji je tada Albaniji omogućavao put u socijalizam. Štoviše, u rezoluciju su stavili da je zadatak KPA udariti po svim neprijateljima jer su neprijatelji linije vezivanja FNRJ i NR Albanije zapravo i neprijatelji socijalizma u Albaniji. Samo se po sebi razumije da je na plenumu osuđen Spiruov neprijateljski rad i da su partijske kadrove vezane uz njega tada micali s visokih položaja.

Bila je to samo prividna i kratkotrajna pobjeda. Na početku 1948. Staljin i sovjetsko vodstvo počeli su uvoditi otvorenu hegemoniju u socijalističkim zemljama. U veljači su Kardelj, Đilas i Bakarić, vodeći političar u Hrvatskoj, bili u Moskvi i tom ih je prilikom Staljin napao zato što se jugoslavenski komunistički vođe nisu konzultirali s njim o slanju divizija u Albaniju. ${ }^{67}$ Za Kardelja je bio pravi šok kada ga je u noći 11./12. veljače Molotov naprasno pozvao da potpiše tekst Ugovora o uzajamnom konzultiranju o vanjskopolitičkim pita-

\footnotetext{
${ }^{63}$ HR-HDA-1798, OF Savo Zlatić, kut. 6, Izvještaji CK, depeše, nedatirani spis.

${ }^{64}$ HADALIN, Boj za Albanijo, 159-160.

${ }^{65}$ HR-HDA-1798, OF Savo Zlatić, kut. 6, Izvještaji i depeše CK.

${ }^{66}$ HADALIN, Boj za Albanijo, 162-165.

${ }^{67}$ PETRANOVIĆ, Zapisnici sa sednica Politbiroa Centralnog komiteta KPJ, 637; ŽIVOTIĆ, Jugoslavija, Albanija i velike sile, 298-302.
} 
njima između Vlade Sovjetskoga Saveza i Vlade Jugoslavije. ${ }^{68}$ Odnosi Sovjetskoga Saveza i FNRJ tako su već u ožujku zapali u tešku krizu, što je značilo da će projugoslavenska struja u KPA izgubiti svoj oslonac na Jugoslaviju jer će ova biti odbačena od socijalističkih zemalja i prisiljena mijenjati svoju vanjsku politiku. Prije svoje pobjede početkom ožujka Xoxe i njegovi ljudi već su bili definitivno poraženi.

\section{Vojno savezništvo uoči prekida odnosa}

Uz gospodarske, najvažniji odnosi Jugoslavije i Albanije bili su vojni. ${ }^{69} \mathrm{Ti}-$ jekom 1947. u njima se nije u tolikoj mjeri reflektiralo nerazumijevanje i razilaženje partijskih vrhova kao što je to bio slučaj u gospodarskim odnosima. Hadalin tumači da je micanje Spirua jugoslavenska strana shvatila kao mogućnost da i u vojnim odnosima zbliži Jugoslaviju i Albaniju. ${ }^{70}$ Jugoslavenska vojna delegacija na čelu s general-lajtnantom Radom Hamovićem posjetila je Tiranu od 24. do 29. prosinca 1947. godine. Jugoslaveni su tada predložili da se izgled albanske oružane sile odredi prema jedinstvenom ratnom planu Jugoslavenske armije, a da njezin operativni plan postane sastavni dio zajedničkoga operativnog plana, te da se albansko Ministarstvo obrane podredi svim uredbama i pravilnicima Jugoslavenske armije i da se svi albanski časnici školuju u FNRJ. Čak se išlo toliko daleko da se opskrba albanske vojske željela uključiti u jugoslavenski vojni proračun, prilikom čega bi se određivalo kakvu bi robu i materijale Albanija primala. ${ }^{71}$ Gdje je tu bilo prostora za sovjetsku vojnu suradnju s Albanijom i njihovo slično starateljstvo nad albanskim oružanim snagama? Naime, već od jeseni 1946. sovjetska vojna i gospodarska pomoć Albaniji porasla je, a broj vojnih i gospodarskih savjetnika naglo je rastao. ${ }^{72}$ Tito i suradnici bili su upoznati sa sovjetskom vojnom pomoći i tijekom 1947. slagali su se sa zahtjevom Envera Hoxhe da u svaku pukovniju albanske vojske dođu sovjetski vojni stručnjaci. Čak su predlagali da šef sovjetskih instruktora u Albaniji bude podređen glavnom sovjetskom vojnom savjetniku pri Jugoslavenskoj armiji, kao što su mu bili podređeni sovjetski savjetnici pri svakom zapovjedništvu vojne oblasti u Jugoslaviji. ${ }^{73} \mathrm{Na}$ tragu jugoslavenskih prijedloga o albanskoj vojsci u siječnju 1948. došla je u Albaniju još jedna vojna delegacija FNRJ, ali toga puta s namjerom da zaista promijeni albansku vojsku. ${ }^{74}$ Kao logično objašnjenje tih poteza FNRJ može poslužiti ono Životićevo, koje tumači

\footnotetext{
${ }^{68}$ PETRANOVIĆ, Zapisnici sa sednica Politbiroa Centralnog komiteta KPJ, 639-640.

${ }^{69}$ ŽIVOTIĆ, Jugoslavija, Albanija i velike sile, 228-233.

${ }^{70}$ HADALIN, Boj za Albanijo, 169-170.

${ }^{71}$ Isto, 170-172; ŽIVOTIĆ, Jugoslavija, Albanija i velike sile, 232.

72 ŽIVOTIĆ, Jugoslavija, Albanija i velike sile, 247.

${ }^{73}$ Isto, 260.

${ }^{74}$ HADALIN, Boj za Albanijo, 170-173; ŽIVOTIĆ, Jugoslavija, Albanija i velike sile, 295-296.
} 
da jugoslavensko rukovodstvo nije imalo jasnu predodžbu o sovjetskom pogledu na takvu politiku FNRJ kojom se Albaniju htjelo potpuno vojno podčiniti, i to u osvit prekida odnosa FNRJ i cijeloga sovjetskoga socijalističkog lagera. ${ }^{75}$

\section{Prekid odnosa}

Prekid odnosa započeo je pismima koja su razmjenjivali Enver Hoxha i Josip Broz Tito u ožujku i travnju 1948. godine. Prvi ih je započeo pisati Hoxha, moleći nastavak jugoslavenske pomoći. ${ }^{76}$ Mjesec dana poslije, 20. travnja, Generalštab Jugoslavenske armije povukao je vojne savjetnike. ${ }^{77} \mathrm{U}$ drugom pismu Titu, 21. travnja, Hoxha se žalio na primjedbe vojnoga predstavnika FNRJ da se međusobni sporazumi ne poštuju, odnosno da su mnogi jugoslavenski stručnjaci u pritvoru. U literaturi tema jugoslavenskih stručnjaka u pritvoru u Albaniji u proljeće 1948. nije obrađena. U izvorima nisam pronašao ništa o tome jesu li stručnjaci zaista bili u pritvoru. Hoxha se u pismu požalio i na otkazivanje boravka vojnim savjetnicima. Tito mu je odgovorio 22. travnja sa dva pisma, u kojima je naglasio da se FNRJ povlačenjem vojnih instruktora istovremeno odriče i financiranja albanske vojske i da su uzroci kvarenja odnosa nepovjerenje koje dio albanskih dužnosnika ima prema jugoslavenskima. ${ }^{78}$ Rekao je još da FNRJ više ne može pomagati Albaniji na štetu vlastitoga naroda, a da pritom ta žrtva ne utječe na poboljšanje međusobnih odnosa.

Odnosi dviju zemalja i partija konačno su prekinuti nakon Rezolucije Informbiroa sredinom 1948. i do kraja postojanja Jugoslavije više nisu bili ni dobri ni srdačni.

\section{Zaključak}

Odnosi vrha KPJ i KPA od proljeća 1945. do proljeća 1947. bili su u stabilnoj uzlaznoj putanji. Prigovori i nerazumijevanja između jugoslavenskih i albanskih dužnosnika nisu u tom razdoblju znatnije utjecali na odnose dviju zemalja i partija. Način na koji je FNRJ pomagala NR Albaniji i posve pokroviteljski odnos Jugoslavije prema manjoj saveznici ipak su u mjesecima nakon Drugoga svjetskog rata polako kvarili odnose KPJ i KPA. Patronat jugoslavenske države i KPJ izazvao je krizu u proljeće 1947. odbijanjem albanskoga gospodarskog plana. Dio albanskih komunističkih rukovoditelja htio se izvući iz snažnoga stiska svojega partnera. Nerazumijevanja su tada postajala sve izra-

\footnotetext{
${ }^{75}$ ŽIVOTIĆ, Jugoslavija, Albanija i velike sile, 297.

${ }^{76}$ Isto, 309-310.

77 Isto.

${ }^{78}$ HADALIN, Boj za Albanijo, 174-175.
} 
ženija i počela su se sve više prelijevati na odnose između naroda u Albaniji i Jugoslavena na radu u toj zemlji. Planovi o gospodarskoj i vojnoj suradnji, dvama glavnim oblicima odnosa dviju zemalja i partija, sve su se više razilazili. Dok je gospodarska suradnja izazivala sve veće probleme, vojna je krajem 1947. i početkom 1948. doživjela kratkotrajni preporod. Prema literaturi i izvorima može se zaključiti da je taj preporod bio posljedica potrebe, čak nužnosti koju je Enver Hoxha osjećao - da mu zemlju mora štititi jedna veća vojska u uvjetima kada Albaniju nisu priznale zapadne zemlje. Njegova ga je želja da se otme patronatu Tita i KPJ poticala da jača odnose sa Sovjetskim Savezom. Na kraju je u odnosima dviju zemalja i partija presudila vanjskopolitička situacija, odnosno sukob Jugoslavije i Sovjetskoga Saveza, praćenog zemljama socijalističkoga lagera. Odnosi Jugoslavije i Albanije kvarili su se svojom unutarnjom logikom, ali međunarodni sukob izazvan Rezolucijom Informbiroa bio je katalizator konačnoga prekida odnosa.

\section{Arhivski izvori}

HR-HDA-1798, OF Savo Zlatić: Hrvatska, Hrvatski državni arhiv, Zagreb, Osobni fond Savo Zlatić.

\section{Objavljeni izvori i tisak}

Borba (Beograd), 1989.

Komunist (Beograd), 1981.

NIN (Beograd), 1981, 1986.

PETRANOVIĆ, Branko, ur. Zapisnici sa sednica Politbiroa Centralnog komiteta KPJ (11. jun 1945 - 7. jul 1948). Beograd: Arhiv Jugoslavije; Službeni list SRJ, 1995.

Službeni list Demokratske Federativne Jugoslavije (Beograd), 1945.

Službeni list Federativne Narodne Republike Jugoslavije (Beograd), 1946.

\section{Literatura}

BARTL, Peter. Albanci: od srednjeg veka do danas. Beograd: Clio, 2001.

DANYLOW, Peter. Die aussenpolitischen Beziehungen Albaniens zu Jugoslawien und zur UdSSR 1944-1961. München; Wien: Oldenbourg Verlag, 1982.

DEDIJER, Vladimir. Jugoslovensko-albanski odnosi (1939-1948). Beograd: Borba, 1949.

HADALIN, Jurij. Boj za Albanijo: propad jugoslovanske širitve na Balkan. Ljubljana: Inštitut za novejšo zgodovino, 2011.

HADALIN, Jurij. „Naš človek v Tirani. Predstavnik Centralnega komiteja Komunistične partije Jugoslavije pri Centralnem komiteju Komunistične par- 
tije Albanije dr. Savo Zlatić (1912-2007)”. U: Nečakov zbornik: procesi, teme in dogodki iz 19. in 20. stoletja, ur. Kornelija Ajlec, Bojan Balkovec i Božo Repe. Ljubljana: Znanstvena založba Filozofske fakultete, 2018, 497-516.

PEŠIĆ, Milorad. „Relations with Albania”. Review of International Affairs: politics, economics, law, science, culture 32 (1981), br. 749: 13-17.

PLJAKU, Panajot. Nasilje nad albanskom revolucijom. Beograd; Priština: Narodna knjiga; Rilindja; Jedinstvo, 1984.

RANITOVIĆ, Gordan. „Privredni razvoj Albanije”. Marksistička misao (1986), br. 2: 145-162.

STANIČ, Janez. „Albanija Enverja Hoxhe”. U: Albanci, ur. Janez Stanič. Ljubljana: Cankarjeva založba, 1984, 145-163.

SWAIN, Nigel; SWAIN, Geoffrey. Eastern Europe since 1945. Basingstoke; New York: Palgrave Macmillan, ${ }^{4} 2009$.

TOPALOVIĆ, Duško. „Geopolitičke komponente albanskih savezništava”. Marksistička misao (1985), br. 6: 154-159.

TOPALOVIĆ, Duško. „Geopolitički aspekti jugoslovensko-albanskih odnosa”. Marksistička misao (1986), br. 2: 138-144.

VELJOVIĆ, Mile. „Kontinuitet i promene u albanskoj politici”. Međunarodna politika 38 (1987), br. 885: 4-6.

VELJOVIĆ, Mile. „Odnosi Jugoslavije i Albanije”. Međunarodna politika 37 (1986), br. 874: 23-26.

VICKERS, Miranda. From anarchy to a Balkan identity. London: Hurst \& Company, 1999.

ŽIVOTIĆ, Aleksandar. Jugoslavija, Albanija i velike sile: (1945-1961). Beograd: Arhipelag; Institut za noviju istoriju Srbije, 2011. 


\section{SUMMARY}

\section{Relations between the Yugoslav and Albanian Communist Leadership from the End of World War II to the Break-up of Relations (1945-1948)}

The article presents the relationship between the leaders of the Communist Party of Yugoslavia and the leaders of the Communist Party of Albania from the end of World War II till the break-up of relations of the two, namely from the spring of 1945 till mid-1948. This relationship had been of crucial importance in the mentioned period since the two communist parties had totalitarian power and control over their respective countries. Nevertheless, the Albanian communists were junior partners in this close cooperation. The most important fields of cooperation were the economy and military, where Albanians were supposed to receive the help and support of Yugoslavs, and be obedient in return. The Yugoslav side demonstrated a full control over Albanian economic policy by the rejection of the Albanian economic plan in the spring of 1947. Such economic plans were the tools of communists in socialist countries that allowed them to rule their countries and wield overwhelming influence over the people. Having insight into books and articles concerning the topic, the author has discovered that some questions have not yet been fully examined. The archival fonds of the representative of the Yugoslav communists in Albania, Savo Zlatić, have not been used. Furthermore, the sheer volume of the Albanian discontent as to how the Yugoslavs had helped them has not been established so far. Therefore, the aim of this article is to compare different sources and find as many unresolved questions as possible. The topic is politically sensitive and shows how much we may learn about the political history of the $20^{\text {th }}$ century or, in other words, how delicate research about political history may be, given the lack of many studies that would examine myriad relevant topics and thus prepare the conditions to make syntheses about this topic as precise and complete as possible.

The reports and writings of Savo Zlatić open up the world of misunderstandings and conflicts between the two countries and instil doubts as to whether these conflicts had something to do with differences between the peoples of the two countries, differences that the Marxist-Leninist way of thinking and approach was not capable of dealing with.

Key words: Albanian communists; Yugoslav communists; economic cooperation; military cooperation; economic plan; conflicts 